\title{
EDUKASI TENTANG COVID-19 SERTA PEMANFAATAN TANAMAAN HERBAL PADA PEDAGANG JAMU KELILING DI DESA TANJUNGSARI
}

\section{EDUCATION ABOUT COVID-19 AND THE UTILIZATION OF HERBAL PLANTS IN JAMU KELILING TRADERS IN TANJUNGSARI}

\author{
Muhammad Nur Fathoni \\ Pendidikan Apoteker, Fakultas Farmasi, Universitas Airlangga \\ email : muhammad.nur.fathoni-2017@ ff.unair.ac.id
}

\begin{abstract}
Covid-19 is one of disease that has been spread worldwide in Indonesia and the world right now. This pandemic causing of activities in all sector is disturbed. It's need to prevent of the spreading this virus absolutely. The purpose of this event is to improving knowledge about the implementation of health protocol and utilization of herbs plant as Jamu for improving body's health. As a target is Jamu's seller in Tanjungsari village, Pacitan sub-district, Pacitan Regency and to the general public and the method is educating dan socialization by divided to several step of the activities, first step, that is spreading pamflet about covid-19 and it's prevention on social media as media for socialization and educating to the public. Secondly, socialization and educating jamu's seller using pamflet as media for socialization and continued by distributing masker and handsanitizer with educating them how to use it properly. The result is there are improvement significantly, especially for jamu's seller about covid-19 and utilization herb plants as effort to maintenance body's health.
\end{abstract}

Keywords : covid-19, jamu, socialization, educating, herbs plant, masker and handsanitizer

\section{abstrak}

Covid-19 merupakan penyakit yang sedang mewabah di Indonesia dan dunia. Adanya pandemi ini menyebabkan kegiatan disemua sektor terganggu. Sehingga upaya mencegah penyebaran virus ini mutlak dilakukan. Tujuan kegiatan ini adalah meningkatkan pemahaman penerepan protokol kesehatan dan pemanfatan tanaman herbal sebagai jamu untuk meningkatkan kesehatan tubuh. Sebagai sasaran adalah pedagang jamu Desa Tanjungsari, Kecamatan Pacitan, Kabupaten Pacitan dan masyarakat umum dengan metode sosialisasi dan edukasi dengan beberapa tahap pelaksanaan yaitu, tahap pertama, menyebarkan pamflet tentang covid-19 dan upaya pencegahan pada media massa sebagai media sosialisasi dan edukasi pada masyarkat, kedua, sosialisasi dan edukasi pada pedagang jamu menggunakan pamflet sebagai media sosialisasi dilanjutkan pembagian masker dan handsanitizer serta edukasi bagaimana menggunakan masker dan handsanitizer yang benar. Hasil dari kegiatan ini terdapat peningkatan pemahaman yang signifikan terutama pada pedagang jamu tentang covid-19 dan pemanfaatan tanaman herbal sebagai upaya pemeliharaan kesehatan tubuh.

Kata kunci : covid-19, jamu, sosialisasi, edukasi, tanaman herbal, masker dan handsanitizer

\section{PENDAHULUAN}

Covid-19 merupakah penyakit yang disebabkan oleh virus corona jenis baru. Awal mula dari penyebaran virus ini adalah Wuhan, China. Coronavirus Disease 2019 (COVID-19) adalah penyakit jenis baru yang belum pernah diidentifikasi sebelumnya pada manusia. Virus penyebab COVID-19 ini dinamakan Sars-CoV-2. Virus corona adalah zoonosis (ditularkan antara hewan dan manusia). Penelitian menyebutkan bahwa SARS ditransmisikan dari kucing luwak (civet cats) ke manusia dan MERS dari unta 
ke manusia. Adapun, hewan yang menjadi sumber penularan COVID-19 ini masih belum diketahui (Kemenkes RI, 2020).

Corona virus adalah suatu kelompok virus yang dapat menyebabkan penyakit pada hewan atau manusia. Beberapa jenis coronavirus diketahui menyebabkan infeksi saluran nafas pada manusia mulai dari batuk pilek hingga yang lebih serius seperti Middle East Respiratory Syndrome (MERS) dan Severe Acute Respiratory Syndrome (SARS).

Gejala-gejala COVID-19 yang paling umum adalah demam, batuk kering, dan rasa lelah. Gejala lainnya yang lebih jarang dan mungkin dialami beberapa pasien meliputi rasa nyeri dan sakit, hidung tersumbat, sakit kepala, konjungtivitis, sakit tenggorokan, diare, kehilangan indera rasa atau penciuman, ruam pada kulit, atau perubahan warna jari tangan atau kaki. Gejala-gejala yang dialami biasanya bersifat ringan dan muncul secara bertahap. Beberapa orang menjadi terinfeksi tetapi hanya memiliki gejala ringan(WHO, 2020).

Virus ini dapat ditularkan dari manusia ke manusia dan telah menyebar secara luas di China dan lebih dari 190 negara dan teritori lainnya. Pada 12 Maret 2020, WHO mengumumkan COVID-19 sebagai pandemik. COVID-19 adalah penyakit baru yang telah menjadi pandemi. Penyakit ini harus diwaspadai karena penularan yang relatif cepat, memiliki tingkat mortalitas yang tidak dapat diabaikan, dan belum adanya terapi definitif. Masih banyak knowledge gap dalam bidang ini sehingga diperlukan studistudi lebih lanjut (Adityo Susilo dkk., 2020)

Penyebaran virus ini sangat cepat sehingga semua negara di dunia ini sedang menghadapi masalah kesehatan yang sama. Tak terkecuali di Indonesia. Bebrapa daerah terjadi transmisi lokal, seperti di Pacitan, Jawa Timur. Hingga saat ini di Kabupaten Pacitan pasien konfirmasi positif virus corona sudah mencapai 50-an.Hal itu tentu saja membuat semua orang khawatir akan terjadi penularan yang lebih masif. Untuk mencegah itu, pihak pemerintah telah melakukan berbagai upaya dimulai dari penutupan akses wisata, sosialisasi penerapan protocol kesehatan. Tak terkecuali di Desa Tanjungsari yang merupakan tempat kegiatan Kuliah Kerja Nyata - Belajar Bersama Masyarakat Mandiri Unair ke-62. Masih banyak warga yang kurang memahami virus corona itu sehingga dalam menerapkan protocol kesehatan masyarakat masih terkesan kurang maksimal. Di ruang public masih banyak warga yang tidak menggunakan masker, kurang menjaga jarak, dan kesadaran untuk mencuci tangan setiap melakukan aktifitas dirasa masih kurang.

Di awal virus corona ini masuk Indonesia, di masyarakat banyak beredar informasi bahwa empon-empon dapat menyebuhkan covid-19. Dari permasalahan-permasalahan di atas maka, diperlukan upaya nyata untuk mensosialisasikan serta mengedukasi masyarakat utamanya kelompok dengan latar belakang pendidikan dan ekonomi yang kurang untuk lebih memahami apa itu covid-19 hingga upaya mencegah penularan covid-19. Untuk permasalahan kedua, maka diperlukan edukasi bagi masyarakat bahwa empon-empon itu belum terbukti secara klinis dapat menyembuhkan covid-19, melainkan untuk menjaga kesehatan dari segi imunitas tubuh. Sehingga diperlukan sosialisasi dan edukasi terhadap tanaman-tanaman herbal yang dapat digunakan menjadi jamu, manfaat tanaman herbal tersebut bagi kesehatan, hingga cara 
mengonsumsi jamu tersebut dengan benar. Jamu dapat digunakan juga untuk anakanak. Menurut Geertz (1961) obat tradisional bukan semata-mata hanya untuk wanita namun tersedia pula untuk laki-laki dan anak-anak. Jamu memiliki beberapa keunggulan, seperti toksisitasnya rendah dan efek samping yang ditimbulkan ringan (Andriati \& Wahjudi, 2016).

Dengan demikian diharapkan masyarakat dapat memahami secara komprehensif dan utuh bagaimana harus berperilaku di masa pandemi ini. Terkait dengan tanaman herbal, maka dengan kegiatan ini akan tercapai mayarakat yang pahan akan manfaat tanaman obat keluarga yang merupakan bagian dari tanaman herbal dapat digunakan untuk mencegah virus corona dengan meningkatan imunitas tubuh seseorang. Edukasi dan sosialisasi kepada masyarakat di lakukan dengan metode daring melalui sosial media dengan sasaran masyarat umum. Sasaran kedua adalah pedagang jamu akan dilaksanakan dengan metode tatap muka untuk berinteraksi secara langsung.

\section{METODE PENGABDIAN MASYARAKAT}

Kegiatan Kuliah Kerja Nyata - Belajar Bersama Masyarakat sebagai bentuk pengabdian kepada masyarakat ini dilakukan selama kurang lebih satu bulan dengan berbagai tahap pelaksanaan. Tahap pelaksanaan itu terbagi menjadi 2 garis besar kegiatan yaitu, tahap pertama, menyebarkan pamflet tentang covid-19 dan upaya pencegahan pada media massa sebagai media sosialisasi dan edukasi pada masyarkat, kedua, sosialisasi dan edukasi pada pedagang jamu menggunakan pamflet sebagai media sosialisasi dilanjutkan pembagian masker dan handsanitizer serta edukasi bagaimana menggunakan masker dan handsanitizer yang benar. Sasaran kegiatan ini terbagi menjadi dua, yaitu sasaran adalah pedagang jamu keliling yang berada di wilayah Desa Tanjungsari. Sasaran kedua adalah masyarakat umum. Teknik atau metode kegiatan ini adalah sosialiasi dan edukasi secara langsung kepada penjual jamu keliling, sedangkan pada masyarakat umum dilakukan dengan metode sosialisasi dan edukasi secara daring menggunakan media sosial.

\section{HASIL DAN PEMBAHASAN}

Kegiatan Kuliah Kerja Nyata - Belajar Bersama Masyarakat (KKN - BBM) Mandiri Unair ke-62 yang dilaksanakan di Desa Tanjungsari memiliki tujuan utama untuk meningkatkan pemahaman masyarakat terhadap covid-19 serta memahami tentang pemanfaatan tanaman herbal untuk meningkatkan imunitas tubuh. Kegiatan berlangsung dengan lancar dengan sasaran utaman adalah 20 pedagang jamu keliling dan masyarakat umum. Kegiatan ini dimulai dari tahap persiapan dan pelaksanaan. Tahap persiapan merupakan tahapan yang cukup panjang guna memperoleh hasil yang baik dan berjalannya agenda kegiatan ini dapat berjalan dengan lancar.

Kegiatan pengabdian masyarakat ini dimulai dari pengumpulan materi dan informasi tentang covid-19 secara komprehensif, artinya dilakukan pencarian mulai dari pengertian covid-19 itu sendiri, penyebab, gejala, penanganan, sampai dengan upaya pencegahannya. Dari informasi ini kemudian dibuat inti sari yang mana akan dijadikan bahan materi untuk pembuatan pamflet tentang covid-19 hingga upaya pencegahannya. Perancangan pamflet ini menggunakan teknologi tertentu sehingga dapat dibuat suatu pamflet yang memiliki desain menarik serta informative. Sehingga dapat menarik perhatian dan memudahkan pembaca untuk memahami isi secara keseleuruhan dengan baik. Pamflet ini di unggah pada platform media sosial pelaksana yaitu instagram 
sehingga tujuan pemahaman masyarakat melalui media sosial dapat tercapai. Hasilnya merupakan feedback positif dari para pengguna instagram dengan memberikan like.

Hal lain juga demikian, pelaksana mengumpulkan materi tentang tanaman herbal, manfaat tanaman herbal, cara mengonsumsi tanaman herbal sebagai jamu guna meningkatkan kesehatan tubuh. Dari informasi yang didapatkan kemudian dibuatlah intisari materi yang akan dimuat dalam pamflet tentang jamu tradisional. Perancangan pamflet ini menggunakan teknologi informasi tertentu sehingga dapat dibuat suatu pamflet yang memiliki desain menarik serta informative. Sehingga dapat menarik perhatian dan memudahkan pembaca untuk memahami isi secara keseluruhan dengan baik. Pamflet ini di unggah pada platform media sosial pelaksana yaitu instagram sehingga tujuan pemahaman masyarakat melalui media sosial dapat tercapai. Hasilnya merupakan feedback positif dari para pengguna instagram dengan memberikan like. Kedua hal tersebut merupakan bagaimana pelaksana memproses suatu informasi kemudian menyajikannya kembali dalam bentuk media lain. Sehingga tujuan pemahaman masyarkat umum tentang covid-19 dan pemanfaatan tanaman herbal dapat tercapai

Kegiatan berikutnya merupakan sosialisasi tentang covid-19 dan pemanfaatan tanaman herbal sebagai jamu kepada pedagang jamu keliling yang dilakukan secara langsung pada sasaran. Pada tahap persiapan dialakuakn serangakain persiapan guna menjadikan tujuan sosiaslisasi dan edukasi ini tercapai dengan maksimal. Dimulai dengan melakukan kunjungan kepada pihak pemangku desa, yaitu Kepala Desa Tanjungsari yang dilaksanakan di kantor balai desa tanjungsari. Dari hal tersebut didapatkanlah ijin untuk melaksanakan kegiatan di Desa Tanjungsari engan diberikannya surat rekomendasi dari pihak desa. Kemudian pelaksana mendapatkan data penduduk dan sebaran penduduk yang berprofesi sebagai pedagang jamu keliling untuk memudahkan akses kegiatan.

Persiapan selanjutnya adalah dengan menyiapkan bahan-bahan sebagai sarana pendukung edukasi dan sosialisasi tersebut. Pembuatan pamflet tentang menggunakan masker dan handsanitizer yang benar. Hal itu bertujuan untuk memudahkan pelaksana dalam memberikan edukasi dengan gambar dan desain yang menarik sehingga mudah untuk dipahami oleh sasaran. Kedua, menyiapkan masker dan handanitizer. Penyiapakn keduannya dimulai dari pembuatan label yang mana ditujukan untuk memberikan symbol atau indetitas bahwa kegiatan ini dilaksanakan oleh mahasiswa Unair dalam rangka kegiatan KKN - BBM dengan desain semenarik mungkin. Kemudian label akan dipasangkan pada handsanitizer dan masker. Sarana pendukung lain adalah pamflet tentang upaya pencegahan covid-19 dan pemanfaatan tanaman herbal di atas seperti pada gambar 1.

Pada pelaksanaanya, 20 pedagang jamu keliling ini rata-rata masih rendah pengetahuannya terhadap covid-19. Sehingga hal ini berdampak pada bagaimana mereka berperilaku sehari-hari. Contohnya adalah kesadaran penggunaan masker masih rendah, dan tingkat intesitas mencuci tangan yang cukup rendah. Kemudian sosialisasi dilaksanan dengan mengedukasi mereka tentang bagaimana seharsnya bersikap di masa pandemic ini. Dari uji kualitatif, sasaran menunjukan tingkat pengetahuan yang lebih baik tentang covid-19. Ketika bereka ditanya apa itu covid-19 mereka sudah bisa membedakan antara penyakit dan hal yang menyebabkannya. Mereka lebih paham 
mengenai bagaimana gejala klinis dari covid-19. Mereka juga lebih memahami bagaimana cara utama untuk mencegah penularan covid-19. Antusiasme ini merupakan semangat bersama untuk belajar bersama sehingga dapat meningkatkan kepatuhan mereka dalam menerapkan protocol kesehatan yang telah dibuat pemerintah utamanya ketika mereka berada di ruang public. Mereka juga lebih memahami pentingnya menjaga diri sendiri dan orang lain, kepedulian inilah menjadi slaah satu parameter dalam suksesnya kegiatan ini.

Para pedagang jamu keliling ini, ketika ditanya apa manfaat dan bagaimana cara mengonsumsi jamu dengan benar, sebagian mereka cukup tahu tentang beberapa manfaat jamu, namun hal itu masih dangkal, dan beberapa dari merka kurang memahami manfaat jamu tersebut terlebih bagaimana mengonsumsinya dengan benar. Sosialisasi dilaksanakn pada 20 pedagang jamu keliling ini dengan metode edukasi dengan menggunakan ilustrasi gamabr sehingga memudahkan komunikasi antarpersonal. Hasilnya rata-rata mereka paham bahan apa saja yang dapat dimanfaatkan sebagai jamu. Mereka juga paham apa tanaman-tanaman herbal tersebut bagi kesehatan tubuh. Mereka juga lebih paham bagaimana cara mengonsumsi jamu dengan benar dengan menggunakan takaran yang tepat sesuai dengan penelitian yang ada. Mereka juga menjadi paham siapa-siapa saja yang boleh dan tidak boleh mengonsumsi jamu pada kondisi-kondisi tertentu, misalnya wanita hamil, penderita penyakit kronis, terlebih pada hati, alergi pada bahan tertentu

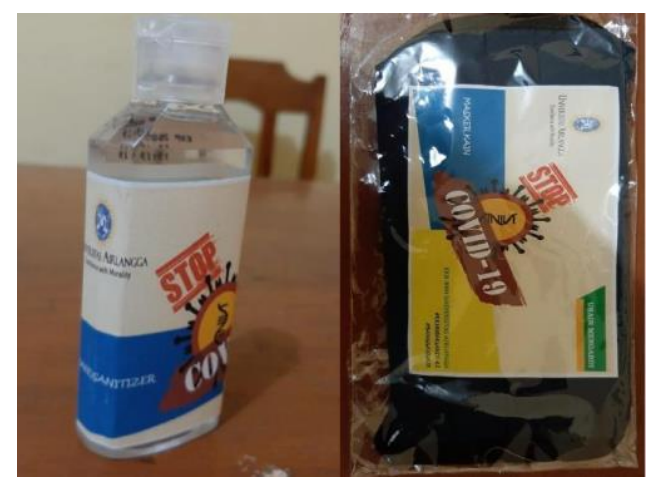

Gambar 1. Hasil pelabelan masker dan Handsanitezer untuk dibagikan kepada pedagang jamu keliling

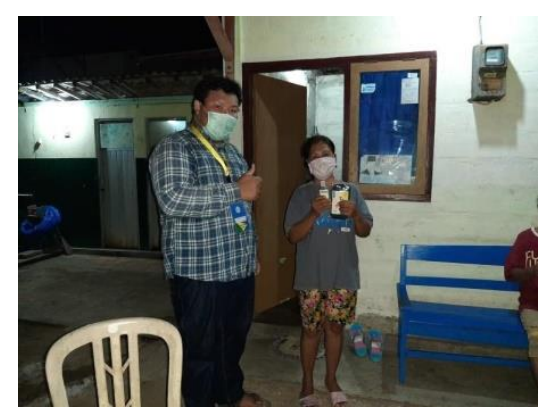

Gambar 2. Pembagian masker dan Handsanitizer pada pedagang jamu keliling hari pertama 


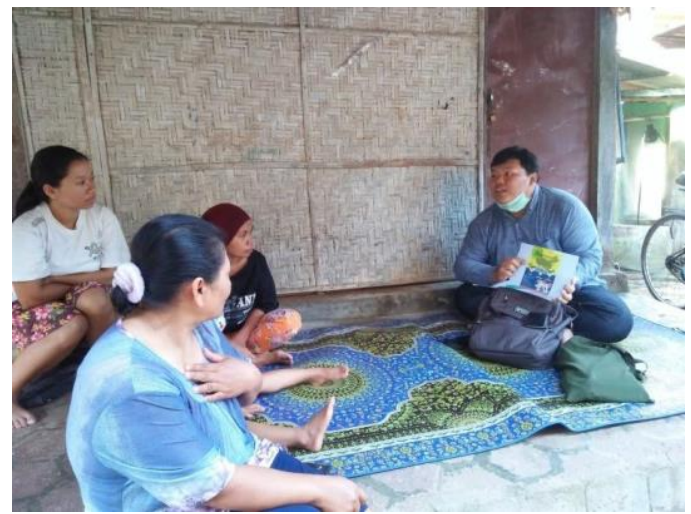

Gambar 3. Sosialisasi dan edukasi tentang covid-19 dan pemanfaatan tanaman herbal sebagai jamu

Kegiatan sosialisasi edukasi kepada mayarakat umum dan khususnya pada 20 pedagang jamu keliling secara umum Dapat dikatakan berjalan dengan lancar dan baik. Proses kegiatan sosialisasi ini terpampang pada gambar 3 dan kegiatan pembagian masker dan handsaniterzer terpampang pada gambar 2. Kegiatan ini sudah menjaab tujuan aal yaitu memberikan pemahaman yang komprehensi bagi pedagang jamu keliling dengan memberikan edukasi dan sosialisasi tentang covid-19 dan pemanfataan tanaman herbal sebagai jamu untuk meningkatkan kesehatan. Dimuali dari pemahaman masing-masing pribadi inilah kemudian diharapkan mereka akan mengimplementasikan protokol kesehatan dalam kegiatan sehari berjualan jamu secara keliling dan dapat turut memberikan informasi manfaat jamu dan cara mengonsumsi jamu dengan benar pada pelanggan jamu masing-masing. Di masa yang akan dating akan lebih baik untuk mengadakan pelatihan pembuatan jamu yang tepat guna meningkatkan kualitas jamu dengan narasumber seorang ahli dalam bidang farmakognosi dan fitokimia.

\section{PENUTUP}

\section{Simpulan}

Kuliah Kerja Nyata - Belajar Bersama Masyarakat (KKN - BBM) Mandiri ke-62 sebagaoi bentuk pengabdian masyarakat dengan kegiatan sosialisasi dan edukasi tentang covid-19 dan pemanfaatan tanaman herbal sebagai jamu untuk meningkatkan kesehatan tubuh di Desa Tanjungsari dengan tujuan untuk memberikan pemahaman terkait hal dia atas secara komprehensif dan tepat pada pedagang jamu keliling berjalan dengan baik dengan tercapainya pemahaman tentang covid-19 dan pemanfaatan tanaman herbal oleh masing-masing pedagang jamu. Masker dan Handsaniter dapat tersalurkan dengan baik dan merata sebagai upaya suportif bagai sasaran dalam bersikap di era pandemic ini. Dari pemahaman tersebut munculah kesadaran diri akan menerapkan protocol kesehatan dalam kehidupan sehari-hari untuk mencegah penularan covid-19 dan timbulnya kesadaran bahwa jamu merupakan bagian supportif untuk meningkatkan kesehatan dengan meningkatkan imunitas tubuh.

\section{Saran}

Kegiatan ini memberikan suatu ide pemikiran baru untuk memberikan suatu pelatihan bagi pedagang jamu keliling tentang cara pembuatan jamu yang baik dan benar guna meningkatkan kualitas produk jamu dan meningkatkan khasiat dari jamu itu sendiri. 
Sehingga baik pedagang jamu dan konsumen dapat mendapatkan manfaat seperti yang dikehendaki.

\section{Ucapan Terima Kasih}

Ucapan terima kasih pelaksana ucapkan kepada semua pihak yang telah mendukung dan memberikan kemudahan dalam menjalankan kegiatan Kuliah Kerja Nyata Belajar Bersama Masyarakat (KKN - BBM) Mandiri ke-62 sebagai bentuk pengabdian masyarakat. Khususnya pada pihak Desa Tanjungsari, Kepala Desa Tanjungsari yang telah memberikan ijin dan data guna memudahkan akses dan pelaksanaan kegiatan ini

\section{DAFTAR PUSTAKA}

Susilo, Adityo dkk. 2020. Corona Virus Disease : Tinjauan Literatur Terkini. Jurnal Ilmu Penyakit Dalam Indonesia Volume 7 nomor 1.

Kemenkes RI. 2020. Pedoman Pencegahan dan Pengendalian Corona Virus Disease (Covid-19). Direktorat Jenderal Pencegahan dan Pengendalian Penyakit

Andrianti dan R.M Teguh, Wahjudi. 2016. Tingkat Penerimaan Penggunaan Jamu Sebagai Alternatif Penggunaan Obat Modern pada Masyarakat ekonomi rendah-menengah dan atas. Jurnal Masyarakat, Kebudayaan dan Politik Volume 29 No. 3

WHO. 2020. Novel Corona Virus : Q and A for public. Di akses melalui :https://www.who.int/indonesia/news/novelcoronavirus/qa-for-public 